\title{
Ichnological analysis at the Fonte Coberta section (Lusitanian Basin, Portugal): Approaching depositional environment during the Toarcian oceanic anoxic event (T-OAE)
}

\author{
Olmo MIGUEZ-SALAS ${ }^{\prime *}$, Francisco J. RODRÍGUEZ-TOVAR \& \& Luis V. DUARTE
}

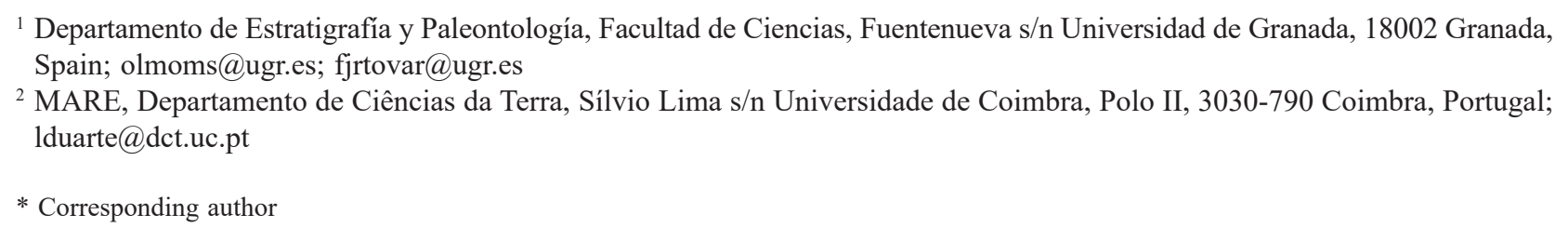

Miguez-Salas, O., Rodríguez-Tovar, F.J. \& Duarte, L.V. 2018. Ichnological analysis at the Fonte Coberta section (Lusitanian Basin, Portugal): Approaching depositional environment during the Toarcian oceanic anoxic event (T-OAE). [Análisis icnológico de la sección Fonte Coberta (Cuenca Lusitánica, Portugal): una aproximación al ambiente de depósito durante el evento anóxico del Toarciense (T-OAE)]. Spanish Journal of Palaeontology, 33 (2), 261-276.

\section{ABSTRACT}

The Toarcian Oceanic Anoxic Event (T-OAE) is commonly related with an extended marine mass extinction and global oceanic anoxic conditions. However, recently it has been demonstrated that local palaeotopography/palaeogeography can determinate the absence of anoxic conditions, being other limiting environmental parameters of higher significance. The detailed study of the Fonte Coberta section (Lusitanian Basin, Portugal) shows significant changes in the macrobenthic community at the lower Toarcian (Levisoni Zone) sediments during the event. In the study section, this interval presents a high degree of bioturbation with a relatively abundant and moderately diverse trace fossil assemblage dominated by Thalassinoides, with punctual Spongeliomorpha. The ichnotaxonomical study conducted on this trace fossil assemblage has allowed the recognition of a single species of Thalassinoides, T. suevicus Rieth, with two different morphotypes (I and II), as well the differentiation of Spongeliomorpha aff. iberica Saporta. The distribution of these ichnospecies, including the differentiated morphogroups,

\section{RESUMEN}

El evento anóxico oceánico del Toarciense (T-OAE en inglés) se relaciona comúnmente con una extinción en masa en el medio marino y condiciones anóxicas oceánicas globales. Sin embargo, recientemente se ha demostrado que la compleja paleotopografía/paleogeografía local puede determinar la ausencia de condiciones anóxicas, siendo otros parámetros ambientales de mayor importancia. El estudio detallado de los sedimentos del Toarciense inferior (Zona Levisoni), en la sección de Fonte Coberta (Cuenca Lusitánica, Portugal), muestra cambios significativos en la comunidad macrobentónica durante el evento. En la sección de estudio, este intervalo presenta un alto grado de bioturbación con una asociación de trazas fósiles relativamente abundante y moderadamente diversa, con predominio de Thalassinoides y aparición puntual de Spongeliomorpha. El estudio iconotaxonómico ha permitido el reconocimiento de una única icnoespecie de Thalassinoides, T. suevicus Rieth, con dos morfotipos diferentes (I y II), así como la diferenciación de Spongeliomorpha aff. iberica Saporta. La distribución de 
along the studied interval, corresponding to the T-OAE, allows refining depositional conditions as changes in the substrate consistency related to variations in relative sea level. Ichnological analysis reveals as a proxy to improve sequence stratigraphy characterization for the Lusitanian Basin during the T-OAE.

Keywords: Trace fossils, Thalassinoides suevicus, T-OAE, sequence stratigraphy, Portugal. estas icnoespecies, incluidos los morfogrupos diferenciados, a lo largo del intervalo estudiado, correspondiente al T-OAE, permite detallar las condiciones de depósito, observándose cambios en la consistencia del sustrato relacionados con las variaciones en el nivel relativo del mar. De esta manera se pone de manifiesto que el análisis icnológico puede ser un valioso indicador a la hora de mejorar la propuesta secuencial de la Cuenca Lusitánica durante el T-OAE.

Palabras clave: Trazas fósiles, Thalassinoides suevicus, T-OAE, estratigrafía secuencial, Portugal.

\section{INTRODUCTION}

In recent years, several studies have proven the potential of trace fossils to improve understanding of mass-extinction events (e.g., Twitchett \& Barras, 2004; Beatty et al., 2008; Fraiser \& Bottjer, 2009; Knaust, 2010; Hofmann et al., 2011; Buatois et al., 2013; Labandeira et al., 2016), because of trace fossils represent the response of trace makers to palaeoenvironmental conditions. Nevertheless most of the ichnological studies are focused on major extinction events, such as the end-Permian (Knaust, 2010; Mata \& Bottjer, 2011) or the end-Cretaceous (RodríguezTovar \& Uchman, 2004a, 2004b, 2006, 2008; RodríguezTovar et al., 2004, 2006, 2010, 2011, 2016; RodríguezTovar, 2005; Kędzierski et al., 2011; Alegret et al., 2015; Monaco et al., 2015; Labandeira et al., 2016; Łaska et at., 2017), while others minor extinction events as the Toarcian Oceanic Anoxic Event (T-OAE) has been comparatively scarcely studied from an ichnological point of view (Rodríguez-Tovar \& Uchman, 2010; Rodríguez-Tovar \& Reolid, 2013; Reolid et al., 2014, 2015; Miguez-Salas et al., 2017; Rodríguez-Tovar et al., 2017).

The T-OAE is considered a global event and one of the most extreme palaeoenvironmental perturbations of the Jurassic, as evidenced by a significant global mass extinction event (Pálfy \& Smith, 2000; Gómez et al., 2008; Wignall \& Bond, 2008; Mattioli et al., 2009; Danise et al., 2015). The T-OAE is characterized by common black shale deposits that reflect the widespread development of poor oxygenation in the oceans, warming in tropical and subtropical seas $\left(\sim 5-8^{\circ} \mathrm{C}\right.$; Gómez et al., 2008), biotic turnovers and negative carbon isotope excursions (CIE) (e.g., Jenkyns, 1988; Hesselbo et al., 2007; Suan et al., 2008, 2011; Littler et al., 2010; Izumi et al., 2012). This event had a significant impact on the marine biota, including benthic and pelagic groups (Hallam, 1996; Wignall et al., 2005; Rodríguez-Tovar \& Uchman, 2010; Comas-Rengifo et al., 2013; Rita et al., 2016; BaezaCarratalá et al., 2017; Correia et al., 2017b). The negative CIEs suggest an input of ${ }^{13} \mathrm{C}$-depleted carbon into the atmosphere-ocean system. Two main hypotheses have been proposed to explain this ${ }^{13} \mathrm{C}$-depleted carbon release and the important environmental changes involved: 1) tectonic extensional mechanisms, which would release methane hydrate in marine sediments (Hesselbo et al., 2000), inducing anoxic conditions, ocean acidification and possibly determining variations in the thermohaline currents (Bjerrum et al., 2001; Trecalli et al., 2012); and 2) the volcanic episode Karoo-Ferrar, which began in the Pliensbachian (lowermost Jurassic) and produced a big thermogenic methane emissions (McElwain et al., 2005; Svensen et al., 2007). These two mechanisms created greenhouse conditions (Pálfy \& Smith, 2000). However, global anoxic conditions can be locally absent due to a strong palaeogeographical control (i.e., McArthur et al., 2008; Rodríguez-Tovar \& Uchman, 2010; RodríguezTovar \& Reolid, 2013; Danise et al., 2015), being other environmental parameters of higher influence on biota (e.g., temperature, salinity, or nutrients availability, among others).

The Lusitanian Basin (LB, Portugal) presents a complex record of the T-OAE; the event significantly affected the marine biota (e.g., Barrón et al., 2013; Cabral et al., 2013; Ferreira et al., 2015; Rita et al., 2016; BaezaCarratalá et al., 2017; Correia et al., 2017a; Miguez-Salas et al., 2017, among others), but the common black shales registered in other European basins (Jenkyns et al., 2001; Röhl et al., 2002; van Breugel et al., 2006), are absent here (Hesselbo et al., 2007; Pittet et al., 2014). In the proximal Rabaçal area, abundant bioturbation is registered associated to the T-OAE in a context of absence of black shales (Miguez-Salas et al., 2017). This record can be influenced by the relative sea-level changes, controlled by tectonics, including the uplift of the emerged areas during the T-OAE, displaying a main role in the control of palaeoenvironmental conditions (Duarte, 1997, 2007; Kullberg et al., 2001; Hesselbo et al., 2007). As pointed out by Pittet et al. (2014) the occurrence of complex palaeotopographies and palaeogeography at the onset of the T-OAE might constitute a pivotal controlling factor in modulating the development of anoxic conditions in epicontinental basins. 
Previous ichnological studies of the T-OAE at the Fonte Coberta section revealed a comparatively minor influence of the oxygenation on the macrobenthic trace maker community, being other parameters, as nutrient availability, or substrate consistency of major importance (Miguez-Salas et al., 2017; Rodríguez-Tovar et al., 2017). Here we present a new detailed ichnotaxonomical study of the lower Levisoni Zone (lower Toarcian) in the Fonte Coberta section, with differentiation at sub-ichnospecies level (morphotypes). This ichnological analysis allows interpret the depositional context affecting the registered response of the macrobenthic tracemaker community and then the minor incidence of the T-OAE event.

\section{GEOLOGICAL SETTING. THE FONTE COBERTA SECTION}

The Fonte Coberta section is located $15 \mathrm{~km}$ south of Coimbra (northwest Portugal, Rabaçal area; 4003'34.3'N - $8^{\circ} 27^{\prime} 34.2^{\prime \prime} W$; Fig. 1) on the northeastern part of the LB, corresponding to the mid-distal part of a carbonate homoclinal ramp that dip to the northwest (Duarte, 1997). The lower Toarcian sediments from this section belong to the lower part of the São Gião Formation (Polymorphum and Levisoni zones), corresponding to three main members, which from the bottom to the top are (Fig. 2):

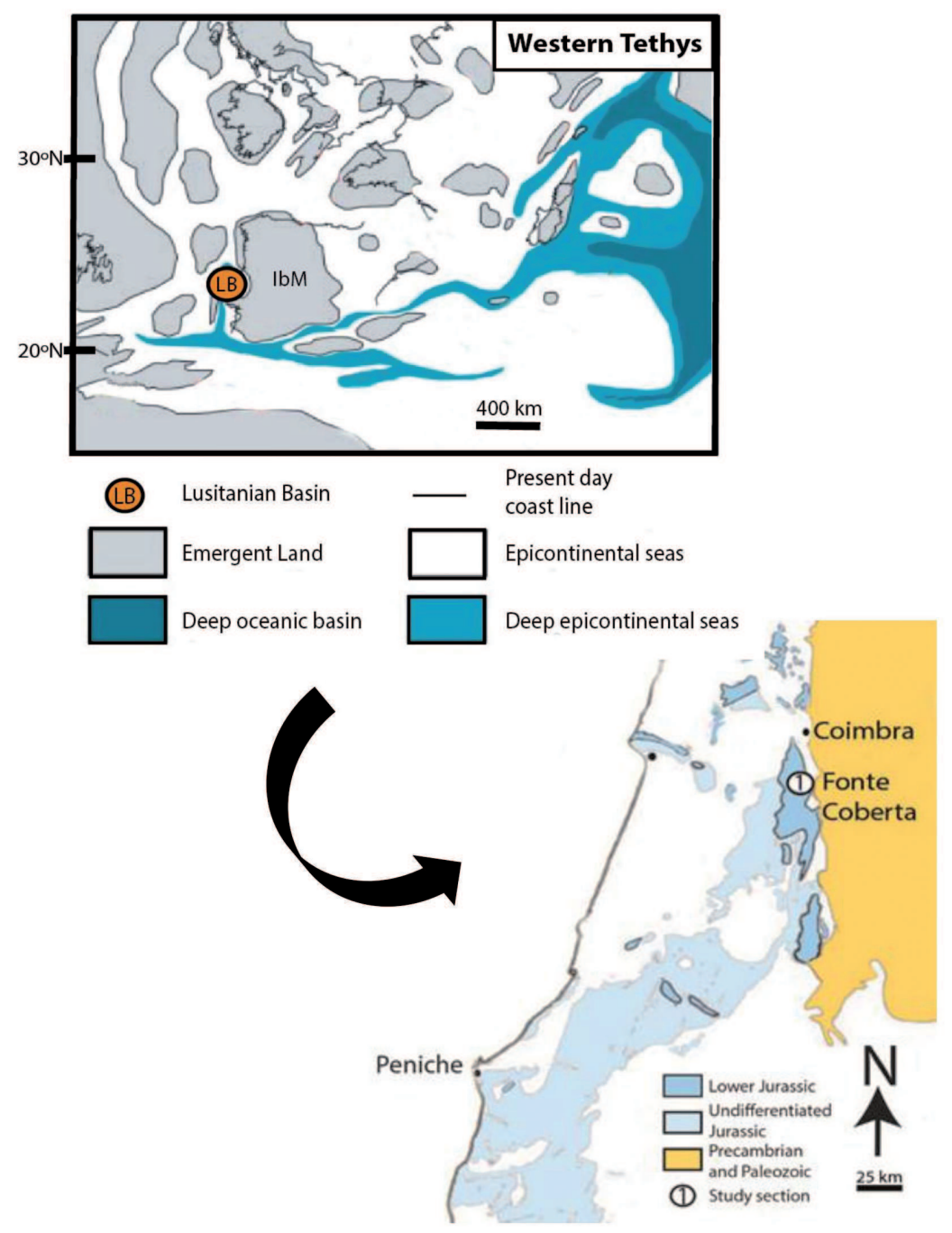

Figure 1. Palaeogeographical representation of the western Tethys with the position of the Lusitanian Basin (LB) during the early Jurassic (based on Dera et al., 2010 and Ferreira et al., 2015) and geological setting (modified from Duarte, 2007); IbM, Iberian Massif. 
1) marly limestones with Leptaena fauna (MLLF); 2) thin nodular limestone (TNL); and, 3) marls and marly limestones with Hildaites and Hildoceras (MMLHH) (Duarte \& Soares, 2002; Duarte et al., 2004; Duarte, 2007). Our study is focused on the 7-meter-thick TNL member, which is characterized by light brown marl-limestone alternations with highly bioturbated limestone layers that cause its nodular aspect. The base of this member corresponds to the boundary between Polymorphum and Levisoni ammonite zones (base of T-OAE) and marks one of the most important palaeontological and sedimentological changes observed in the whole Lower
Jurassic (see Duarte, 1997; Miguez-Salas et al., 2017), including the extinction of the previously well-represented brachiopods community, a decreased in the abundance of ammonoids and the disappearance of the previous record of Zoophycos (Duarte, 1997; Comas-Rengifo et al., 2013) (Fig. 2a).

In terms of sedimentological features, the beginning of the TNL at the Fonte Coberta section is marked by a change in the coloration of the marls, from grayish in the MLLF member to brownish in the TNL member (intervals Ra-2 and Ra-3) (Fig. 2a); besides the thickness of the marls is thinner (centimetrical) than in the previous member.
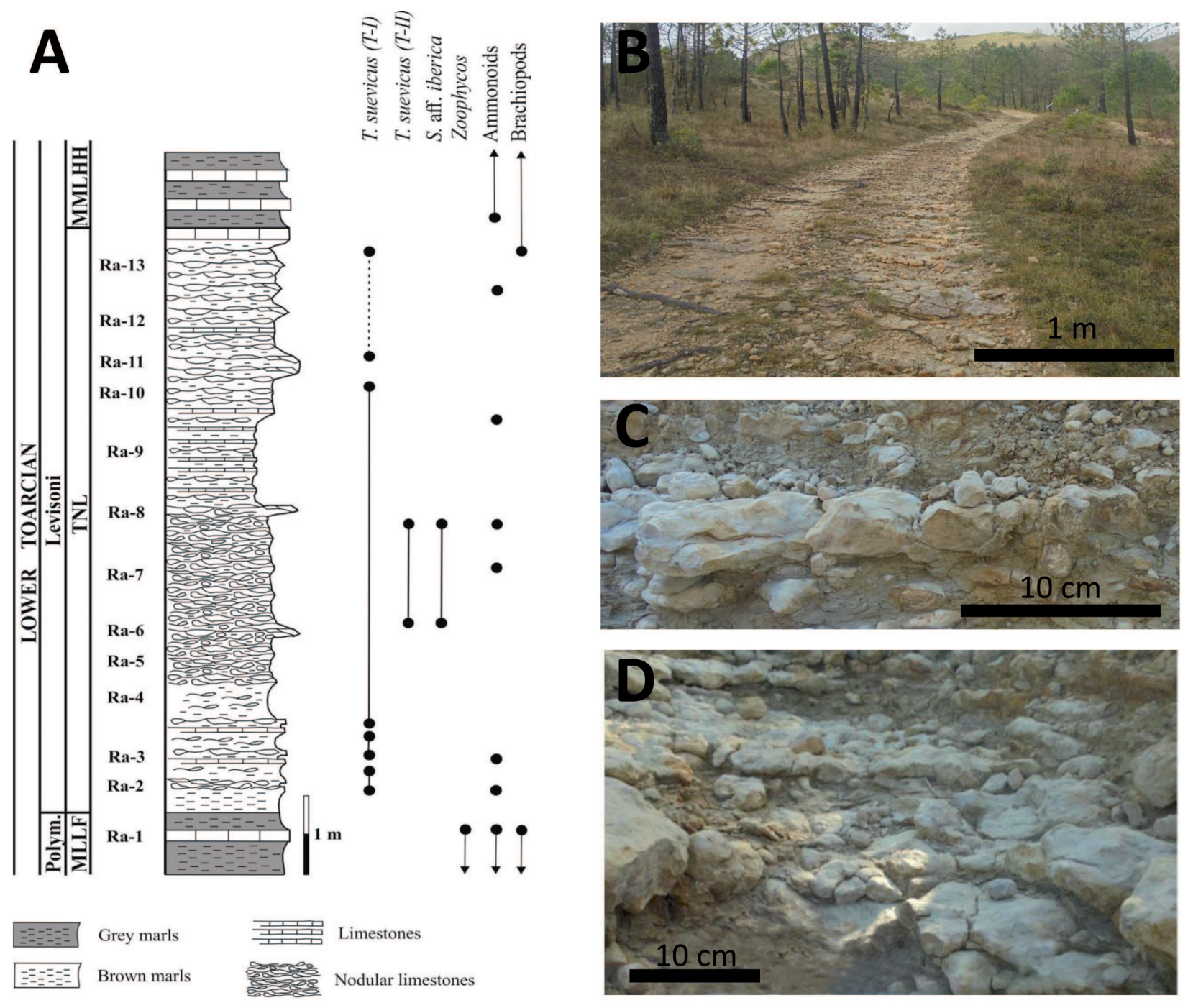

Figure 2. a) Lithological column of the Fonte Coberta section showing distribution of ammonoids, brachiopods, Zoophycos, $T$. suevicus (type I and II) and S. aff. iberica. MLLF = Marly limestones with Leptaena facies member; TNL = Thin nodular limestones member; MMLHH = Marly limestones with Hildaites and Hildoceras member (modified from Miguez-Salas et al., 2017). b) Outcrop view of the TNL member in the Fonte Coberta section. c-d) Close-up views of middle part of the TNL member (Ra 6 and 7). 
The nodular limestone levels, mainly observed from intervals Ra-5 to Ra- 8 , record an increase in abundance of bioturbation from beds Ra-2 to Ra-7. Intervals from Ra-6 to Ra-8 present scarce marly inter-bedding and a more calcareous character (conspicuous appearance). From interval Ra-9 to the end of Ra-10 a progressive diminution of the nodularity, together with an increase in thickness of the clay levels, is observed (Miguez-Salas et al., 2017). Finally, at the top of the TNL member (from Ra-11 to Ra-13), the section returns to more grayish marly facies, with a clear increase in macroinvertebrates (especially brachiopods and ammonoids with dominance of Hildaites and Hildoceras, see Comas-Rengifo et al., 2013).

\section{RESULTS. TRACE FOSSIL ANALYSIS}

Trace fossil features, including ichnofabrics, were reexamined in detail from bottom to top of the TNL member. The trace-fossil assemblage reveals significant changes in abundance and diversity throughout the section. The abundance increases from the base until the middle part of the TNL member and then decreases progressively to the top of the member. Ichnotaxonomic diversity changes run parallel to the trace-fossil abundance. Ichnotaxonomical analysis allows ichnospecies characterization, and even intra-specific differentiation, into the previously recognized ichnogenera Thalassinoides and Spongeliomorpha.

Ichnogenus Thalassinoides Ehrenberg, 1944

Type species Thalassinoides callianassae (Ehrenberg) from the Burdigalian Stage of the Vienna basin (Ehrenberg, 1944, p. 358).

Diagnosis. The ichnogenus Thalassinoides Ehrenberg (1944) comprises cylindrical to elliptical burrows systems with regular branching, which form a three-dimensional polygonal network with both horizontal and vertical elements connected to the surface; external surfaces of the burrow are usually smooth.

Palaeoecological remarks of Thalassinoides. The record of Thalassinoides has been associated to a number of palaeoenvironmental conditions (Rodríguez-Tovar et al., 2008). As a general interpretation, an abundant record of Thalassinoides can be considered as indicative of welloxygenated environments (Bromley \& Frey, 1974; Kern \& Warme, 1974; Ekdale \& Bromley, 1984; Bromley, 1990). Ocassionaly, Thalassinoides has been also registered in salinity or temperature stressed environments (e.g., Howard \& Frey, 1975; MacEachern \& Gingras, 2007; Dashtgard et al., 2008; Gingras et al., 2011). Thalassinoides occurs from softgrounds to firmgrounds and in some cases are recorded in association with the first stages of hardground surfaces (Ekdale \& Bromley, 1984; Ekdale, 1992; Myrow, 1995; Pemberton et al., 2004).

Ichnospecies of Thalassinoides. The species accepted to the ichnogenus Thalassinoides are: $T$. saxonicus (Geinitz, 1842), T. ornatus (Kennedy, 1967), T. paradoxicus (Woodward, 1830), T. suevicus (Rieth, 1932), T. horizontalis (Myrow, 1995), T. bacae (Ekdale \& Bromley, 2003) and T. sifangpoensis Wang, 2004. Other proposed ichnospecies that are no longer accepted or whose validity is questioned are T. tandoni (Badve \& Ghare, 1978) and T. foedus (Mikuláš, 1990) (Fürsich, 1973; Keighley \& Pickerill, 1997; Rodríguez-Tovar et al., 2008; Yanin \& Baraboshkin, 2013).

Thalassinoides saxonicus is characterized by its large tunnels with diameters between 5 and $20 \mathrm{~cm}$ (Kennedy, 1967). T. ornatus refers to smaller ovate $(0.8 \times 1.6 \mathrm{~cm}$ to $1 \times 2.2 \mathrm{~cm}$ ), horizontal to gently inclined burrows (Kennedy, 1967). T. paradoxicus corresponds to burrows where branches form complex boxwork systems, usually with T-shaped bifurcations, and highly irregular in size and geometry (Kennedy, 1967; Howard \& Frey, 1984; Frey \& Howard, 1985). T. suevicus is a predominantly horizontal structure with dominant Y-shaped bifurcations that may contain enlargements at the branching point (Howard \& Frey, 1984). T. horizontalis is a strictly horizontal form with relative small diameter as well as a diagenetically wall lining. T. bacae refers to irregularly anastomosing, horizontal tunnel mazes with highly variable branching angles and numerous vertical shafts (Ekdale \& Bromley, 2003). T. sifangpoensis is a small netting burrow system, the sizes of the net being $3 \mathrm{~mm} \times 5 \mathrm{~mm}-5 \mathrm{~mm} \times 8 \mathrm{~mm}$ and the diameters of burrow 0.5-1.0 mm (Wang, 2004).

Description. The studied specimens of Thalassinoides appears on the limestone layers from the bottom to the top of the TNL member (Figs 2b-d). They are well preserved, although their lateral continuity is short. The structures show a dominant horizontal development, with irregular branches, and the near absence of vertical components (Figs 3-4).

The burrow systems are cylindrical or subcylindrical in cross-section with diameters that varies between 1.5 and 6 $\mathrm{cm}$ (Table 1). The main feature of the studied specimens is a higher frequency of Y-shaped than T-shaped bifurcations. In the case of Y-shaped bifurcations, a big swelling at their junctions is common (Fig. 3a), which is comparatively less developed in the T-shaped forms (Fig. 4a). The angle of Y-shaped bifurcations is normally between $55^{\circ}-80^{\circ}$ (Figs 3d-g). Locally short dead-end chambers seem to be observed (Fig. 3a). External surfaces of burrow casts are usually smooth. In some cases, wall burrow peaks are observed; according to Nickell \& Atkinson (1995) this could be related to irrigation offshoots (Figs 4a-b; dashed 

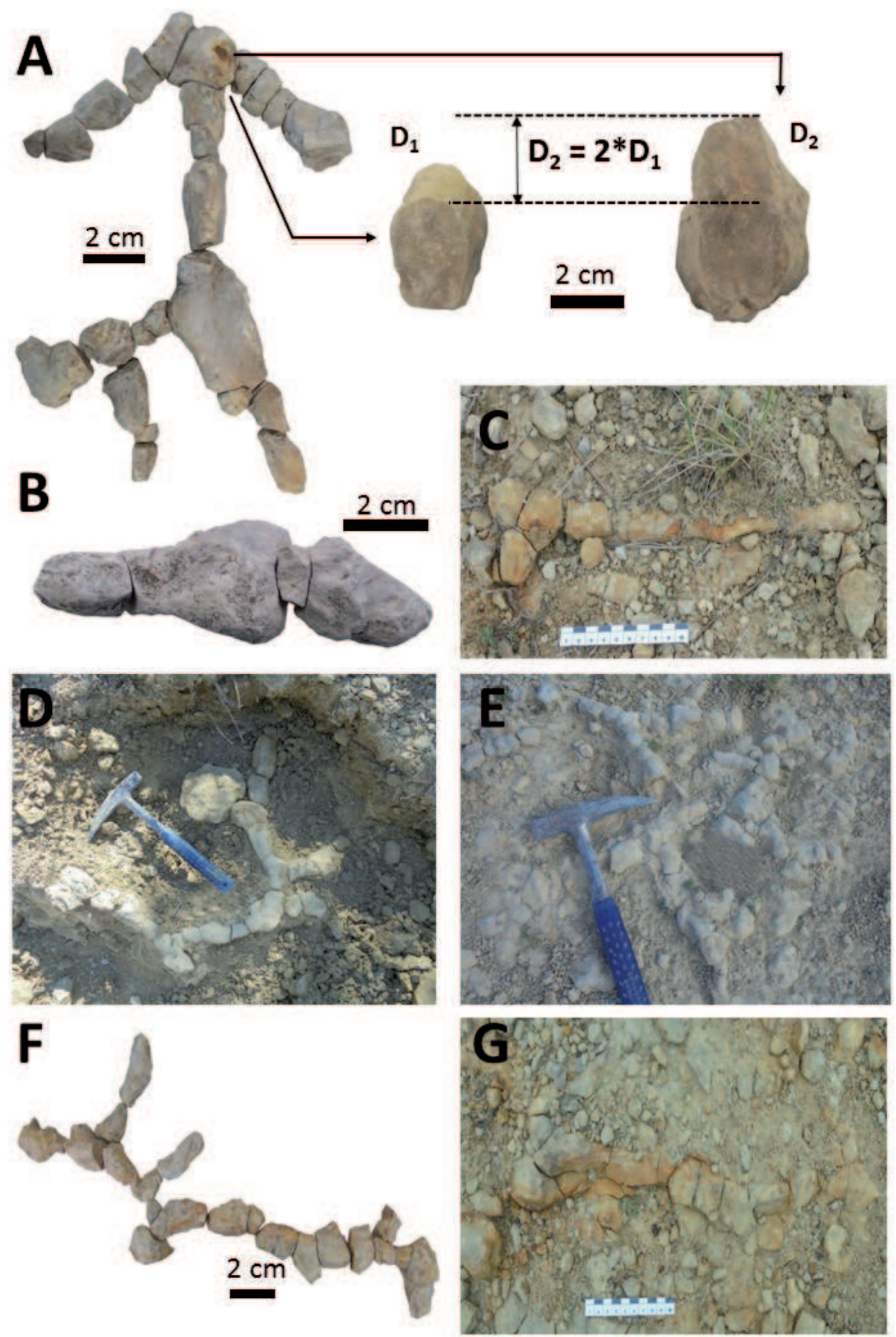

Figure 3. Specimens of T. suevicus from the outcrop in Fonte Coberta section and after laboratory cleaning and digital treatment. a) T. suevicus type I where can be appreciated a big increase at branching point and possibly short dead-end chambers b-c) Specimens of T. suevicus type I. d-e) Specimens of T. suevicus type II. f-g) Specimens of T. suevicus type I. 


\begin{tabular}{|c|c|c|c|c|c|c|}
\hline & $\begin{array}{c}\text { Average } \\
\text { diameter }(\mathrm{cm})\end{array}$ & Lenght $(\mathrm{cm})$ & $\begin{array}{c}\text { Minimum } \\
\text { diameter }(\mathrm{cm})\end{array}$ & $\begin{array}{c}\text { Maximun } \\
\text { diameter }(\mathrm{cm})\end{array}$ & $\begin{array}{c}\text { Increase at } \\
\text { branching point }(\mathrm{cm})\end{array}$ & $\begin{array}{c}\text { Bifurcation } \\
\text { angle }\end{array}$ \\
\hline 2-Th1 & 2.3 & 18 & 2 & 3 & 0.7 & $60^{\circ}$ \\
\hline 3-Th1 & 2.2 & 55 & 1.9 & 3 & 0.8 & $75^{\circ}$ \\
\hline 3-Th2 & 2.1 & 34 & 1.8 & 2.6 & 0.5 & $80^{\circ} / 60^{\circ}$ \\
\hline 3-Th3 & 2 & 46 & 1.8 & 2.8 & 0.8 & $65^{\circ}$ \\
\hline 3-Th4 & 1.9 & 22 & 1.5 & 2.1 & $\mathrm{x}$ & $\mathrm{x}$ \\
\hline 3-Th5 & 2.4 & 24 & 2.2 & 3 & 0.6 & $73^{\circ}$ \\
\hline 4-Th1 & 1.8 & 36 & 1.5 & 2.4 & 0.6 & $66^{\circ}$ \\
\hline 5-Th1 & 2.3 & 51 & 1.9 & 2.7 & 0.4 & $58^{\circ} / 72^{\circ}$ \\
\hline $5-\operatorname{Th} 2$ & 2 & 32 & 1.6 & 2.8 & 0.8 & $\mathrm{x}$ \\
\hline 5-Th3 & 2.3 & 24.3 & 2 & 2.6 & 0.3 & $77^{\circ}$ \\
\hline 5-Th4 & 2.4 & 55 & 2 & 3 & $\mathrm{x}$ & $55^{\circ}$ \\
\hline 5-Th5 & 2 & 18 & 1.7 & 2.7 & 0.7 & $80^{\circ}$ \\
\hline 5-Th6 & 2 & 15.5 & 1.6 & 2.3 & $\mathrm{x}$ & $\mathrm{x}$ \\
\hline $5-\operatorname{Th} 7$ & 2 & 32 & 1.7 & 2.5 & 0.5 & $62^{\circ}$ \\
\hline 6-Th1 & 2.8 & 40 & 2.3 & 3.7 & 0.9 & $76^{\circ} / 65^{\circ}$ \\
\hline $6-T h 2$ & 2.2 & 16 & 1.8 & 2.7 & $\mathrm{x}$ & $\mathrm{x}$ \\
\hline 6-Th3 & 4.5 & 79 & 3.1 & 6 & 1.5 & $68^{\circ}$ \\
\hline 7-Th1 & 2.2 & 52 & 1.9 & 2.5 & 0.3 & $59^{\circ}$ \\
\hline 7-Th2 & 2.3 & 17 & 1.8 & 2.8 & 0.5 & $55^{\circ} / 67^{\circ}$ \\
\hline 7-Th3 & 2.5 & 16.5 & 2 & 4 & 1.5 & $\mathrm{x}$ \\
\hline 7-Th4 & 2.3 & 31 & 2 & 2.8 & 0.5 & $73^{\circ}$ \\
\hline 7-Th5 & 3 & 35 & 2.7 & 4 & 1 & $79^{\circ}$ \\
\hline 11-Th1 & 2.2 & 19 & 1.9 & 3.2 & 1 & $63^{\circ}$ \\
\hline 13-Th1 & 2.4 & 12 & 2 & 3 & $\mathrm{x}$ & $\mathrm{x}$ \\
\hline
\end{tabular}

Table 1. Thalassinoides measurements. In grey T. suevicus type II.

line). The tubular wall lining is usually missing or poorly preserved (Fig. 4d), only in few occasions inside the burrow a lining can be distinguished (Fig. 4d). Specimens with smaller diameters ( 1.5 to $2.5 \mathrm{~cm}$ ) present an exclusive horizontal development and lack of vertical offshoots, constant burrow diameter, and preferential T-shaped bifurcations where vertical swellings at bifurcation points are notably absent (Figs 4c-f).

Ichnotaxonomical classification. According to the ichnological features above indicated, most of the studied specimens in the Fonte Coberta section belong to Thalassinoides suevicus. However, observed variations allow a more detailed characterization into the ichnospecies level. Traditionally different types of $T$. suevicus were described according to the range of sizes. Fürsich (1998) recognized three types: small (type $\mathrm{C}, 0.3-0.7 \mathrm{~cm}$ wide), intermediate (type B, 1-2 cm), and large (type A, 2.5$4 \mathrm{~cm}$ ) structures. Monaco \& Garassino (2001) and Monaco \& Giannetti (2002) proposed a new four-type size classification from smaller to larger diameter: type I (2-4 cm), type II $(4-7 \mathrm{~cm})$, type III $(9-10 \mathrm{~cm})$, and type IV (14-16 cm), always considering an enlargement at branching points.

Most of the collected specimens of T. suevicus could be assigned to type I (Figs 3a-c, 4a-f; Table 1), based on size diameter, together with the presence of features similar to those observed in type I by Giannetti et al. (2007), as the branches tend to be circular in section, the turning chambers are not particularly developed, and the mazes are developed only on the horizontal plane. Moreover, when these burrows are tiered with the other forms of Thalassinoides, they occupy the upper tier. The specimens of T. suevicus with larger diameter are less common in the studied section and can be assigned to type II, also showing features resembling those observed by Giannetti et al. (2007), e.g., development of turning chambers, long branches forming geometrical mazes, and smooth external surface without lining (Figs 3d, g; Table 1).

Ichnogenus Spongeliomorpha Saporta, 1887

Type ichnospecies Spongeliomorpha iberica Saporta, 1887.

Diagnosis. Cylindrical to subcylindrical burrow systems with predominant horizontal elements, which shows Y or T-shaped bifurcations. Burrow terminations are conical, tapered or hemispherical but uninflated. Burrow walls are unlined and ornamented with deep ridges, which are longitudinal, oblique or transverse to the main axis of the trace sensu Melchor et al. (2009). 

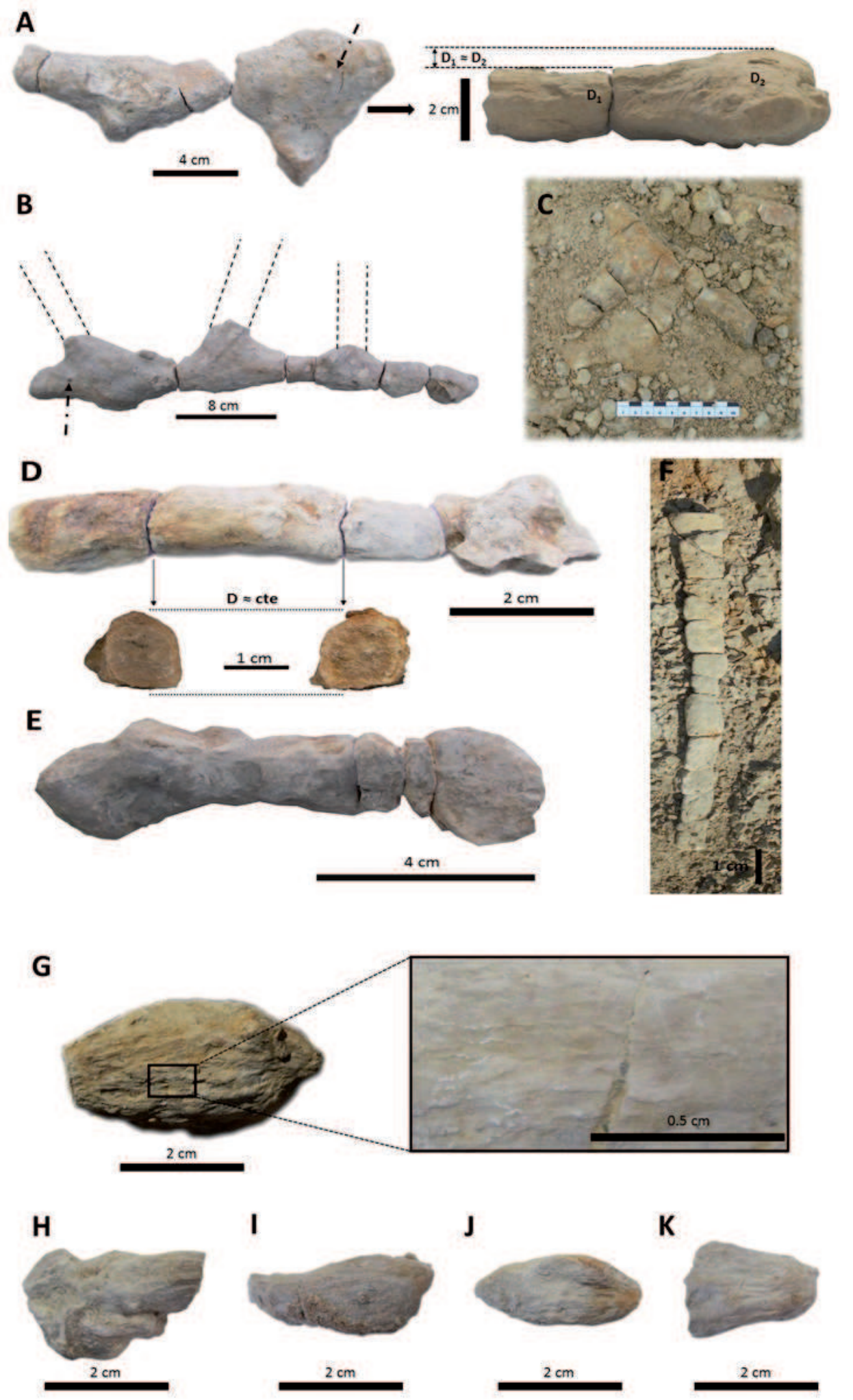

Figure 4. a) Specimens of T. suevicus type I with T-shaped bifurcation that present less vertical swelling at the bifurcation point, identification of possible exhalation shaft (dashed arrow). b) T. suevicus type I with combined $\mathrm{T}$ and $\mathrm{Y}$ shaped bifurcation and possible exhalation shaft (dashed arrow). c-f) Specimens of T. suevicus type I. g-k) Specimens of S. aff. iberica from the Fonte Coberta section. 
Palaeoecological remarks of Spongeliomorpha. This ichnogenus is commonly interpreted as the domicile structure of crustaceans in firm or semi-consolidated substrates as the scratch marks produced by locomotory organs reveals (Frey et al., 1984). Spongeliomorpha is a facies-crossing form that appears on a wide range of environments, from shallow to deep-marine, as well as fresh-water settings. This trace fossil is recorded over different environmental parameters like oxygenation, salinity, temperature, etc. (Frey et al., 1984; Buatois \& Mángano, 1998, 2011; Uchman, 1998). The main control on the formation of extensive Spongeliomorpha horizons seems to be the substrate consistency (Muñiz \& Mayoral, 2001; Ekdale \& de Gibert, 2010; de Gibert \& Ekdale, 2010).

Ichnospecies of Spongeliomorpha. In the revision of Muñiz \& Mayoral (2001), they report various ichnospecies following the ichnotaxobases proposed by Calzada (1981) and added the orientation of the scratch traces with respect to the burrow axis as an important criterion for the ichnospecies differentiation. Recently, Melchor et al. (2009) report that some of them did not belong to the ichnogenus because they do not fit the diagnostic features. Thus, Melchor et al. (2009) consider that the remaining ichnospecies that belong to Spongeliomorpha are: S. iberica, with scratch marks forming a reticulate pattern or longitudinal "Y"-shaped bioglyph and ridges (de Gibert \& Ekdale, 2010); S. chevronensis Muñiz $\&$ Mayoral, 2001, exhibiting ridges oblique to the main axis of the burrow; S. sicula D'Alessandro \& Bromley, 1995, characterised by longitudinal ridges and striated, vertical chambers (also considered Spongeliomorpha isp. nov. aff. sicula by Lewy \& Goldring, 2006); and S. carlsbergi (Bromley \& Asgaard, 1979), which shows dominantly oblique to transverse surface ridges.

Description. The studied specimens appear on the limestone layers (Ra-7) (Fig. 2a), showing a variable preservation (Figs 4g-k). Structures present an exclusive horizontal development, but not well-extended cylindrical or subcylindrical burrow systems are observed; only individual burrow segments are recorded. Thus, elements like Y or T-shaped bifurcations are not observed. Crosssections are subcircular to ovate and width of the tunnel varies from 15 to $22 \mathrm{~mm}$. Some conical burrow terminations are recorded (Fig. 4g). Burrow walls are clearly unlined, showing deep asymmetrical longitudinal ridges that run parallel or subparallel to the main burrow axis, also some longitudinal "Y"-shaped bioglyphs are appreciated (Fig. 4g).

Ichnotaxonomical classification. According to the features mentioned above, the ichnotaxobases proposed by Muñiz \& Mayoral (2001) and the emended ichnotaxonomical diagnosis proposed by Melchor et al. (2009), we can tentatively assign the specimens to $S$. aff. iberica.

\section{DISCUSSION}

\subsection{Sequence stratigraphy at the Lusitanian Basin}

During the last years, detailed sedimentological researches allowed a significant improvement in the sequence stratigraphy framework for the Toarcian of the Lusitanian Basin (e.g., Duarte et al., 2001, 2004, 2007; Duarte, 2007; Pittet et al., 2014). The lower Toarcian succession belongs to a second-order depositional sequence (ST), which is dated from the earliest Toarcian to the early Aalenian and includes the whole São Gião Formation (Duarte, 2007). Into this lower Toarcian part of the second order sequence, the Polymorphum and Levisoni zones of the Rabaçal area are organized into two third-order depositional sequences (ST1 and ST2) separated by discontinuity DT2 (Duarte et al., 2004; Duarte, 2007) (Fig. 5). This boundary between the Polymorphum and Levisoni zones is also associated to an important tectonic activity (Duarte, 1995, 1997; Kullberg et al., 2001; Duarte et al., 2004). The ST1, corresponding to the Polymorphum Zone, is interpreted as a transgressive system tract where isotopic data record an increased trend of $\delta{ }^{13} \mathrm{C}$ that reach maximum values around $+2.6 \%$ just below DT2 (Duarte, 1997; Duarte et al., 2004). This phase is correlated with the deposition of MLLF member, which is the most argillaceous marl/marly limestone (micrite to biomicrite/wackestone) succession of the entire Toarcian (Duarte \& Soares, 2002). This member is represented by well developed brachiopod species such as Koninckella liasina, Nannirhynchia pygmaea, and Pseudokingena deslongchampsi that characterize "Koninckella Fauna", which is characteristic of relatively deep zones (Vörös, 2002; Comas-Rengifo et al., 2013).

The transgressive system tract associated with the MLLF is capped by DT2 that coincides with Polymorphum/ Levisoni boundary (Fig. 5). This discontinuity is related to important sedimentological changes observed at basin scale. In fact, the basal Levisoni Zone is characterized by strong facies variation that includes chocolate marls in northern sections, calcarenites-calcisiltites with storm influence, and turbidites at Peniche (Wright \& Wilson, 1984; Duarte, 1997; Duarte et al., 2004; Suan et al., 2010; Pittet et al., 2014; Rodrigues et al., 2016). These changes in lithology and the variable depositional environments have been attributed to the pre-existing basin morphology with marked topographies (Pittet et al., 2014) as a consequence of regional tectonic pulses (Kullberg et al., 2001), directly related with the Berlenga uplift (see Wright \& Wilson, 1984; Duarte, 1997, 2007; Duarte et al., 2004). In terms of sequence stratigraphy interpretation, as the result of this tectonic event, the infill of the base of Levisoni Zone has been interpreted as a lowstand (Duarte et al., 2004, 2007), induced by a rapid relative sea level fall. This lowstand system tract ends on top of the TNL member by the record 


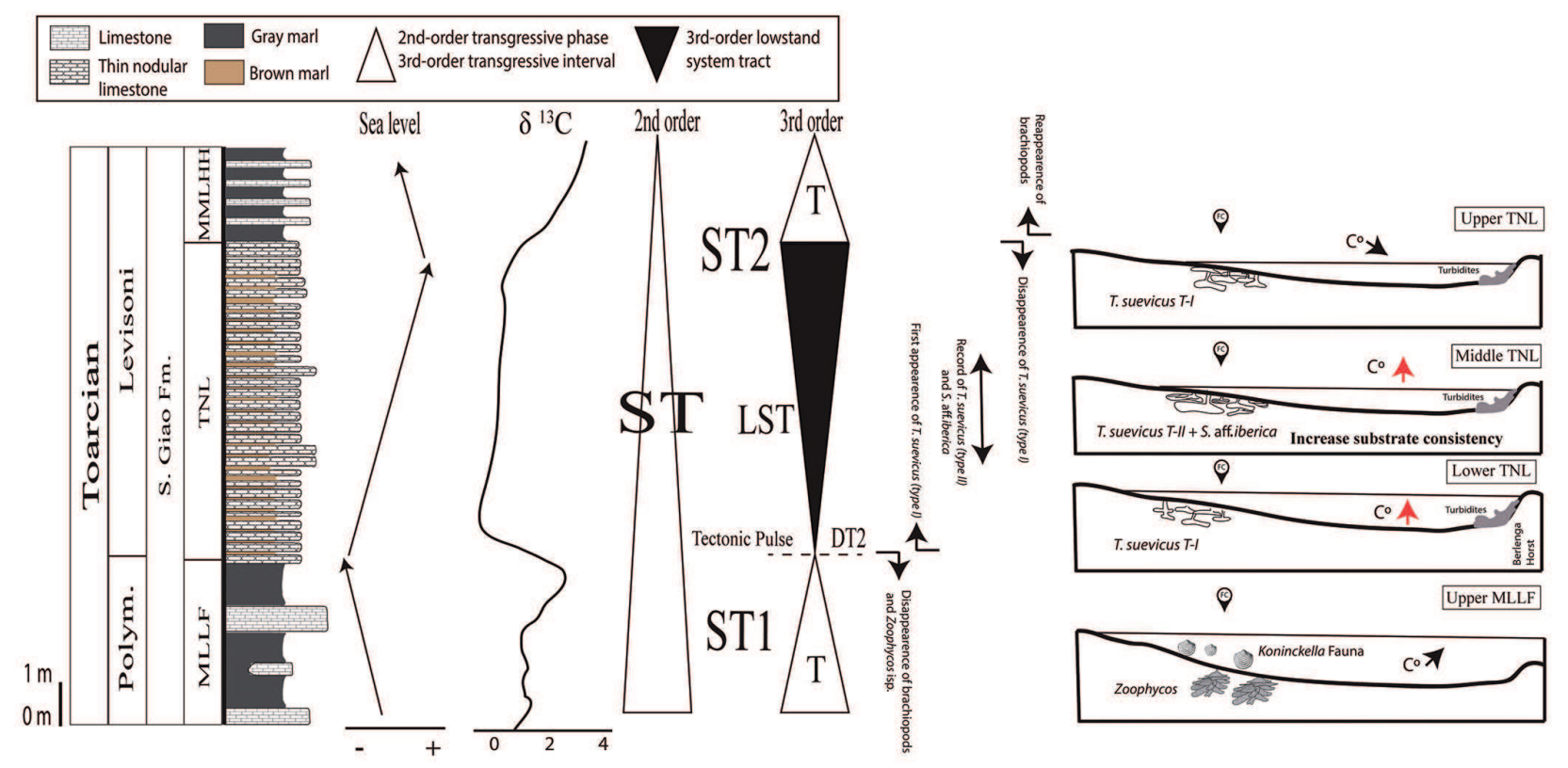

Figure 5. Summary stratigraphic and sedimentological chart of the lower Toarcian succession at LB: lithostratigraphy, sequence stratigraphy (second and third-order sequences), sedimentary characteristics, carbon-isotopic record and schematic palaeoenvironmental succession based on ichnotaxonomical interpretation (modified from Duarte et al., 2004; Duarte, 2007; Rodrigues et al., 2016). DT2 = 3rd-order sequence boundary; ST = 2nd-order depositional sequence; ST1 and ST2 = 3rdorder depositional sequences; $\mathrm{T}=$ transgressive interval; LST $=3$ rd-order lowstand system tract; FC = Fonte Coberta Section.

of a new transgressive event materialised by decimetric to metric marl-limestone alternations of the MMLHH member (Duarte et al., 2004, 2007).

\subsection{Ichnological record and sequence stratigraphy framework}

Ichnological analysis shows to be very useful in sequence stratigraphy analysis by both, the recognition and interpretation of genetically related sedimentary packages, and the characterization of several-order discontinuities of sequence stratigraphy significance (RodríguezTovar, 2010, for a review). Stratigraphic evolution of trace fossil assemblages, mainly related to changes in substrate consistence associated to variations in the rate of sedimentation induced by changes in the relative sea level, allowed characterization of third-order system tracts (Rodríguez-Tovar \& Nieto, 2013; Nieto et al., 2014). On the other hand, presence of particular ichnotaxa, as Diplocraterion or Rhyzocorallium, was used as useful maker in sequence stratigraphy by the recognition of several-order discontinuity surfaces (Olóriz \& RodríguezTovar, 2000; Rodríguez-Tovar et al., 2007; RodríguezTovar \& Pérez-Valera, 2008).

In the case study, in a context of a trace fossil assemblage dominated by Thalassinoides suevicus, it is especially interesting the coincidence in the same beds at the middle part of the TNL member (Ra-7) of Thalassinoides suevicus type II and S. aff. iberica. As indicated above, Spongeliomorpha is mainly interpreted as related to firm or semi-consolidated substrates, while Thalassinoides is common in softgrounds, although occurs in a range of substrate consistencies, including firmgrounds and in the first stages of hardgrounds development (Ekdale \& Bromley, 1984; Rodríguez-Tovar et al., 2008; ElSabbagh et al., 2017). The presence of T. suevicus type II, with larger diameter than T. suevicus type I, showing long branches forming geometrical mazes, could be related with larger trace makers that bioturbated more consolidate substrates. Thus, the dominant presence of T. suevicus type I can be interpreted as revealing a generalized context of soft, but fairly cohesive substrate conditions, punctuated by the occasional increase in substrate consistency favouring bioturbation by Thalassinoides suevicus type II and $S$. aff. iberica trace makers. This agrees with the observed changes in lithofacies features. The generalized nodular limestones show a significant change from the lower part of TNL member, with thinner limestone layers and some thick brown marls intervals, characterized by exclusiveness of $T$. suevicus type I, to the middle of TNL member, with thicker limestones layers and thinner marly inter-beds (Ra6 to Ra-8), where T. suevicus type II and S. aff. iberica are observed. 
The interpreted variations in substrate consistency revealed by the record of Thalassinoides suevicus type II and $S$. aff. iberica, could be associated to: 1) minor-order erosions that could determine the exhumation of concealed firmgrounds, or 2) changes in the rate of sedimentation during the proposed lowstand system tract; a decrease of sedimentation rate allowed a higher compaction of the sediment on the sea floor and then development of firmgrounds conditions.

Firmground Glossifungites ichnofacies are commonly recorded in association with major stratigraphic surfaces (Pemberton et al., 2004, and references therein). In the study case, the only appearance of two ichnogenera (Thalassinoides and Spongeliomorpha) cannot allow us a reliable assignation to the Glossifungites ichnofacies, although some erosive surfaces can be observed in the base of the limestone layers. The firmground ichnogenus Spongeliomorpha has been commonly associated to flooding (transgressive) events (de Gibert \& Robles, 2005), but de Gibert \& Ekdale (2010) also report the appearance of $S$. aff. iberica in shallow water facies in an erosional regressive context. Furthermore, firmground assemblages with coeval appearance of Thalassinoides and Spongeliomorpha have been identified previously in lowstand conditions (see MacEachern et al., 1992; Pemberton \& MacEachern, 1995).

On the other hand, lithological changes into the TNL member, from Ra- 6 to Ra-8, represented by scarce marly inter-bedding and a more calcareous character can be related with decreasing in sedimentation rate. During these periods a higher compaction of the sediment on the sea floor took place, allowing the development of firmground conditions. Besides, recent studies shows that slower sedimentation rate allowed the formation of extensive and bigger T. suevicus burrow systems (Abdel Fattah et al., 2010; Whicher et al., 2016; El-Sabbagh et al., 2017). For a more precise evaluation of these two alternative hypotheses, further studies are necessary in more sections from proximal to distal parts of the ramp along the LB.

\section{CONCLUSIONS}

Detailed ichnological study conducted on the Fonte Coberta section at the Lusitanian Basin, shows that during the Toarcian oceanic anoxic event the marly-calcareous succession suffers a high endobentonic activity as reflected the abundance of bioturbation, revealing favourable palaeoecological conditions for trace makers, including oxygen availability. The low impact of environmental conditions associated with the anoxic event, can be the consequence of local conditions determined by a strong palaeotopographic/palaeogeographic control. Ichnological analysis shows the occurrence of horizontal structures, with differentiation of two ichnogenus: 1) dominant
Thalassinoides, with exclusiveness of the ichnospecies $T$. suevicus, and the differentiation of morphotypes I and II, characterized by a predominant horizontal development and more frequent Y-shaped than T-shaped bifurcations, and 2) frequent Spongeliomorpha, tentatively assigned to $S$. aff. iberica, where asymmetrical longitudinal ridges and some "Y" shaped bioglyphs are the main features. The coeval appearance of $T$. suevicus type II and $S$. aff. iberica along the studied interval, together with the associated lithological changes (scarce marly inter-bedding and a more calcareous character of lithofacies), are interpreted as reflecting increase in the substrate consistency during development of a third order lowstand system tract. The exhumation of concealed firmgrounds due to erosional phases is the most plausible explanation, although decrease in the sedimentation rates cannot be discarded.

\section{ACKNOWLEDGEMENTS}

We thank reviewers Drs. Mayoral (Univ. Huelva) and Reolid (Univ. Jaén), for their valuable suggestions and comments on the manuscript. Also, we sincerely acknowledge the associate editor G. Jiménez-Moreno. The study has been funded by project CGL2015-66835-P (Secretaría de Estado de I+D+I, Spain), Research Group RNM-178 (Junta de Andalucía), and Scientific Excellence Unit UCE-2016-05 (Universidad de Granada). The research of Miguez-Salas is funded through a pre-doctoral grant from the Ministerio de Educación, Cultura y Deporte and a research grant from the Spanish Society of Palaeontology.

\section{REFERENCES}

Abdel-Fattah, Z.A., Gingras, M.K., Caldwell, M.W. \& Pemberton, S. 2010. Sedimentary environments and depositional characteristics of the Middle to Upper Eocene whale-bearing succession in the Fayum Depression, Egypt. Sedimentology, 57, 446-476; doi: 10.1080/10420940.2016.1185010.

Alegret, L., Rodríguez-Tovar, F.J. \& Uchman, A. 2015. How bioturbation obscured the Cretaceous-Palaeogene boundary record. Terra Nova, 27, 225-230; doi: 10.1111/ ter.12151.

Badve, R.M. \& Ghare, M.A. 1978. Jurassic ichnofauna of Kutch. Biovigyanam, 4, 125-140.

Baeza-Carratalá, J.F., Reolid, M. \& García Joral, F. 2017. New deep-water brachiopod resilient assemblage from the South-Iberian Palaeomargin (Western Tethys) and its significance for the brachiopod adaptive strategies around the Early Toarcian Mass Extinction Event. Bulletin of Geosciences, 92, 233-256; doi: 10.3140/bull.geosci.1631. 
Barrón, E., Comas-Rengifo, M.J. \& Duarte, L.V. 2013. Palynomorph succession of the Upper PliensbachianLower Toarcian of the Peniche section (Portugal). Comunicações Geologicas 100, (Especial I), 55-61.

Beatty, T.W., Zonneveld, J.-P. \& Henderson, C.M. 2008. Anomalously diverse Early Triassic ichnofossil assemblages in Northwest Pangea: a case for a shallow-marine habitable zone. Geology, 36, 771-774; doi: 10.1130/G24952A.1.

Bjerrum, Ch.J., Surlyk, F.J., Callomon, H. \& Slingerland, R.L. 2001. Numerical paleoceanographic study of the Early Jurassic Transcontinental Laurasian Seaway. Paleoceanography, 16, 390-404; doi: 10.1029/2000PA000512.

Bromley, R.G. 1990. Trace Fossils: Biology and Taphonomy. Unwin \& Hyman, London.

Bromley, R.G. \& Frey, R.W. 1974. Redescription of the trace fossil Gyrolithes and taxonomic evaluation of Thalassinoides, Ophiomorpha and Spongeliomorpha. Bulletin of the Geological Society of Denmark, 23, 311-335.

Bromley, R.G. \& Asgaard, U. 1979. Triassic freshwater ichnocoenoses from Carlsberg Fjord, East Greenland. Palaeogeography, Palaeoclimatology, Palaeoecology, 28, 39-80; doi: 10.1016/0031-0182(79)90112-3.

Buatois, L.A. \& Mángano, M.G. 1998. Trace fossil analysis of lacustrine facies and basins. Palaeogeography, Palaeoclimatology, Palaeoecology, 140, 367-382; doi: 10.1016/S0031-0182(98)00020-0.

Buatois, L.A. \& Mángano. G.M. 2011. Ichnology: OrganismSubstrate Interactions in Space and Time. Cambridge University Press, Cambridge.

Buatois, L.A., Angulo, S. \& Mángano, M.G. 2013. Onshore expansion of benthic communities after the Late Devonian mass extinction. Lethaia, 46, 251-261; doi: 10.1111/ let.12001.

Cabral, M.C., Loureiro, I.M., Duarte, L.V. \& Azerêdo, A.C. 2013. Registo da extinção dos Metacopina (Ostracoda, Crustacea) no Toarciano de Rabaçal, região de Coimbra. Comunicações Geológicas 100, (Especial I), 63-68.

Calzada, S. 1981. Revisión del icno Spongeliomorpha iberica Saporta, 1887 (Mioceno de Alcoy, España). Boletín de la Real Sociedad Española de Historia Natural (Geología), 79, 189-195.

Comas-Rengifo, M.J., Duarte, L.V., García Joral, F. \& Goy, A. 2013. Os braquiópodes do Toarciano inferior (Jurássico) da região de Rabaçal-Condeixa (Portugal): distribuição estratigráfica e paleobiogeografia. Comunicações Geológicas 100, (Especial I), 37-42.

Correia, V.F., Riding, J.B., Fernandes, P., Duarte, L.V. \& Pereira, Z. 2017a. The palynology of the lower and middle Toarcian (Lower Jurassic) in the northern Lusitanian Basin, western Portugal. Review of Palaeobotany and Palynology, 237, 75-95; doi: 10.1016/j.revpalbo.2016.11.008.

Correia, V.F., Riding, J.B., Duarte, L.V., Fernandes, P. \& Pereira, Z. 2017b. The palynological response to the Toarcian Oceanic Anoxic Event (Early Jurassic) at Peniche, Lusitanian Basin, western Portugal. Marine Micropaleontology, 137, 46-63; doi: 10.1016/j. marmicro.2017.10.004.
D’Alessandro, A. \& Bromley, R.G. 1995. A new ichnospecies of Spongeliomorpha from the Pleistocene of Sicily. Journal of Paleontology, 69, 393-398; doi: 10.1017/ S0022336000034727.

Danise, S., Twitchett, R.J. \& Little, C.T.S. 2015. Environmental controls on Jurassic marine ecosystems during global warming. Geology, 43, 263-266; doi: 10.1130/G36390.1.

Dashtgard, S.E., Gingras, M.K. \& Pemberton, S.G. 2008. Grain-size controls on the occurrence of bioturbation. Palaeogeography, Palaeoclimatology, Palaeoecology, 257, 224-243; doi: 10.1016/j.palaeo.2007.10.024.

de Gibert, J.M. \& Ekdale, A.A. 2010. Paleobiology of the crustacean trace fossil Spongeliomorpha iberica in the Miocene of southeastern Spain. Acta Palaeontologica Polonica, 55, 733-740; doi: 10.4202/app.2010.0010.

de Gibert, J.M. \& Robles, J.M. 2005. Firmground ichnofacies recording high-frequency marine flooding events (Langhian transgression, Vallès-Penedès Basin, Spain). Geologica Acta, 3, 295-305.

Dera, G., Neige, P., Dommergues, J.L., Fara, E., Laffont, R. \& Pellenard, P. 2010. High-resolution dynamics of Early Jurassic marine extinctions: the case of PliensbachianToarcian ammonites (Cephalopoda). Journal of the Geological Society, 167, 21-33; doi: 10.1144/001676492009-068.

Duarte, L.V. 1995. O Toarciano da Bacia Lusitaniana. Estratigrafia e Evolução Sedimentogenética. $\mathrm{PhD}$. Thesis, Universidade de Coimbra, 349 p.

Duarte, L.V. 1997. Facies analysis and sequential evolution of the Toarcian-Lower Aalenian series in the Lusitanian Basin (Portugal). Comunicações do Instituto Geológico e Mineiro, 83, 65-94.

Duarte, L.V. 2007. Lithostratigraphy, sequence stratigraphy and depositional setting of the Pliensbachian and Toarcian series in the Lusitanian Basin (Portugal). In: The Peniche Section (Portugal) (ed. Rocha, R.B.). Contributions to the definition of the Toarcian GSSP. International Subcommission on Jurassic Stratigraphy, 17-23.

Duarte, L.V. \& Soares, A.F. 2002. Litostratigrafia das séries margo-calcárias do Jurássico inferior da Bacia Lusitânica (Portugal). Comunicações do Geológico e Mineiro, 89, 115-134.

Duarte, L.V., Krautter, M. \& Soares, A.F. 2001. Bioconstructions à spongiaires siliceux dans le Lias terminal du Bassin lusitanien (Portugal): stratigraphie, sédimentologie et signification paléogéographique. Bulletin Societe Géologique du France, 172, 637-646; doi: 10.2113/172.5.637.

Duarte, L.V., Perilli, N., Dino, R., Rodrigues, R. \& Paredes, R. 2004. Lower to Middle Toarcian from the Coimbra region (Lusitanian Basin, Portugal): Sequence stratigraphy, calcareous nannofossils and stable-isotope evolution. Rivista Italiana di Paleontologia e Stratigrafia, 100, 115-127.

Duarte, L.V., Oliveira, L.C. \& Rodrigues, R. 2007. Carbon isotopes as a sequence stratigraphic tool: examples from the Lower and Middle Toarcian marly limestones of Portugal. Boletín Geológico y Minero, 118, 3-18.

Ehrenberg, K. 1944. Erganzende Bemerkungen zu den seinerzeit aus dem Miozan von Burgschleinitz beschriebenen 
Gangkernen und Bauten dekapoder Krebse. Paläontologishe Zeitschrift, 23, 345-359.

Ekdale, A.A. 1992. Muckraking and mudslinging: the joys of deposit-feeding. Short Courses in Paleontology, 5, 145-171.

Ekdale, A.A. \& Bromley, R.G. 1984. Sedimentology and ichnology of the Cretaceous- Tertiary boundary in Denmark: implications for the causes of the terminal Cretaceous extinction. Journal of Sedimentary Petrology, 54, 681-703.

Ekdale, A.A. \& Bromley, R.G. 2003. Paleoethologic interpretation of complex Thalassinoides in shallowmarine limestones, Lower Ordovician, southern Sweden. Palaeogeography, Palaeoclimatology, Palaeoecology, 192, 221-227; doi: 10.1016/S0031-0182(02)00686-7.

Ekdale, A.A. \& de Gibert, J.M. 2010. Paleoethologic significance of bioglyphs: fingerprints of the subterraneans. Palaios, 25, 540-545; doi: 10.2110/palo.2009.p09-066r.

El-Sabbagh, A., El-Hedeny, M. \& Al Farraj, S. 2017. Thalassinoides in the Middle Miocene succession at Siwa Oasis, northwestern Egypt. Proceedings of the Geologists' Association, 128, 222-233; doi: 10.1016/j. pgeola.2017.01.001.

Ferreira, J., Mattioli, E., Pittet, B., Cachão, M. \& Spangenberg, J.E. 2015. Palaeoecological insights on Toarcian and lower Aalenian calcareous nannofossils from the Lusitanian Basin (Portugal). Palaeogeography, Palaeoclimatology, Palaeoecology, 436, 245-262; doi: 10.1016/j. palaeo.2015.07.012.

Fraiser, M.L. \& Bottjer, D.J. 2009. Opportunistic behaviour of invertebrate marine tracemakers during the Early Triassic aftermath of the end-Permian mass extinction. Australian Journal of Earth Sciences, 56, 841-857; doi: 10.1080/08120090903002656.

Frey, R.W. \& Howard, J.D. 1985. Trace fossils from the Panther Member, Star Point Formation (Upper Cretaceous), Coal Creek Canyon, Utah. Journal of Paleontology, 59, 370-404.

Frey, R.W., Curran, H.A. \& Pemberton, G.S. 1984. Tracemaking activities of crabs and their environmental significance: the ichnogenus Psilonichnus. Journal of Paleontology, 58, 511-528.

Fürsich, F.T. 1973. A revision of the trace fossils Spongeliomorpha, Ophiomorpha and Thalassinoides. Neues Jahrbuch für Geologie und Paläontologie, Monatshefte, 12, 719-735.

Fürsich, F.T. 1998. Environmental distribution of trace fossils in the Jurassic of Kachchh (Western India). Facies, 39, 243-272.

Geinitz, H.B. 1842. Charakteristik der Schichten und Petrefacten des sächsischböhmischen Kreidegebirges. (Arnoldische Buchhandlung) Dresden und Leipzig.

Giannetti, A., Monaco, P., Caracuel, J.E., Soria, J.M. \& Yébenes, A. 2007. Functional morphology and ethology of decapod crustaceans gathered by Thalassinoides branched burrows in Mesozoic shallow water environments. In: 3rd Symposium on Mesozoic and Cenozoic Decapod Crustaceans (eds. Garassino, A., Feldmann, R.M. \& Teruzzi, G.). Memorie della Società italiana di Scienze naturali e del Museo civico di Storia naturale di Milano, 48-52.
Gingras, M.K., MacEachern, J.A. \& Dashtgard, S.E. 2011. Process ichnology and the elucidation of physico-chemical stress. Sedimentary Geology, 237, 115-134; doi: 10.1016/j. sedgeo.2011.02.006.

Gómez, J.J., Goy, A. \& Canales, M.L. 2008. Seawater temperature and carbon isotope variations in belemnites linked to mass extinction during the Toarcian (Early Jurassic) in Central and Northern Spain. Comparison with other European sections. Palaeogeography, Palaeoclimatology, Palaeoecology, 258, 28-58; doi: 10.1016/j.palaeo.2007.11.005.

Hallam, A. 1996. Major bio-events in the Triassic and Jurassic. In: Global Events and Event Stratigraphy (ed. Walliser, O.H.). Springer, Berlin. 265-283.

Hesselbo, S.P., Gröcke, D.R., Jenkyns, H.C., Bjerrum, C.J., Farrimond, P., Morgans Bell, H.S. \& Green, O.R. 2000. Massive dissociations of gas hydrate during a Jurassic oceanic anoxic event. Nature, 406, 392-395; doi: $10.1038 / 35019044$.

Hesselbo, S.P., Jenkyns, H.C., Duarte, L.V. \& Oliveira, L.C.V. 2007. Carbon-isotope record of the Early Jurassic (Toarcian) Oceanic Anoxic Event from fossil wood and marine carbonate (Lusitanian Basin, Portugal). Earth and Planetary Science Letters, 253, 455-470; doi: 10.1016/j. eps1.2006.11.009.

Hofmann, R., Goudemand, N., Wasmer, M., Bucher, H. \& Hautmann, M. 2011. New trace fossil evidence for an early recovery signal in the aftermath of the end-Permian mass extinction. Palaeogeography, Palaeoclimatology, Palaeoecology, 310, 216-226; doi: 10.1016/j.palaeo.2011.07.014.

Howard, J.D. \& Frey, R.W. 1975. Regional animal-sediment characteristics of Georgia estuaries. Senckenbergiana Maritima, 7, 33-103.

Howard, J.D. \& Frey, R.W. 1984. Characteristic trace fossils in nearshore to offshore sequences, Upper Cretaceous of east-central Utah. Canadian Journal of Earth Sciences, 21, 200-219.

Izumi, K., Miyaji, T. \& Tanabe, K. 2012. Early Toarcian (Early Jurassic) oceanic anoxic event recorded in the shelf deposits in the northwestern Panthalassa: evidence from the Nishinakayama formation in the Toyora area, west Japan. Palaeogeography, Palaeoclimatology, Palaeoecology, 315316, 100-108; doi: 10.1016/j.palaeo.2011.11.016.

Jenkyns, H.C. 1988. The early Toarcian (Jurassic) anoxic event; stratigraphic, sedimentary and geochemical evidence. American Journal of Science, 288, 101-151.

Jenkyns, H.C., Gröcke, D.R. \& Hesselbo, S.P. 2001. Nitrogen isotope evidence for watermass denitrification during the Early Toarcian (Jurassic) oceanic anoxic event. Paleoceanography, 16, 593-603; doi: 10.1029/2000PA000558.

Kędzierski, M., Rodríguez-Tovar, F.J., Uchman, A., 2011. Vertical displacement and taphonomic filtering of nannofossils by bioturbation in the Cretaceous-Palaeogene boundary section at Caravaca, SE Spain. Lethaia, 44, 321328; doi: 10.1111/j.1502-3931.2010.00244.x.

Keighley, D.G. \& Pickerill, R.K. 1997. Systematic ichnology of the Mabou and Cumberland groups (Carboniferous) of 
western Cape Breton Island, eastern Canada, 1: burrows, pits, trails, and coprolites. Atlantic Geology, 33, 181-215.

Kennedy, W.J. 1967. Burrows and surface traces from the Lower Chalk of southern England. Bulletin British Museum of Natural History, Geology, 15, 127-167.

Kern, J.P. \& Warme, J.E. 1974. Trace fossils and bathymetry of the Upper Cretaceous Point Loma formation, San Diego, California. Geological Society of America Bulletin, 55, 893-900.

Knaust, D. 2010. The end-Permian mass extinction and its aftermath on an equatorial carbonate platform: insights from ichnology. Terra Nova, 22, 195-202; doi: 10.1111/j.13653121.2010.00934.X.

Kullberg, J.C., Olóriz, F., Marques, B., Caetano, P.S. \& Rocha, R.B. 2001. Flat-pebble conglomerates: a local marker for Early Jurassic seismicity related to syn-rift tectonics in the Sesimbra area (Lusitanian Basin, Portugal). Sedimentary Geology, 139, 49-70; doi: 10.1016/S0037-0738(00)00160-3.

Labandeira, C.C., Rodríguez-Tovar, F.J. \& Uchman, A. 2016. The End-Cretaceous Extinction and Ecosystem Change. In: The Trace-Fossil Record of Major Evolutionary Events (eds. Mángano, G.M. \& Buatois, L.A.). Topics in Geobiology 40. Springer, Dordrecht, 265-300.

Łaska, W., Rodríguez-Tovar, F.J. \& Uchman, A. 2017. Evaluating macrobenthic response to the CretaceousPalaeogene event: a high-resolution ichnological approach at the Agost section (SE Spain). Cretaceous Research, 70, 96-110; doi: 10.1016/j.cretres.2016.10.003.

Lewy, Z. \& Goldring, R. 2006. Campanian crustacean burrow system from Israel with brood and nursery chambers representing communal organization. Palaeontology, 49, 133-140; doi: 10.1111/j.1475-4983.2005.00532.x.

Littler, K., Hesselbo, S.P. \& Jenkyns, H.C. 2010. A carbonisotope perturbation at the Pliensbachian-Toarcian boundary: evidence from the Lias Group, NE England. Geological Magazine, 147, 181-192; doi: 10.1017/ S0016756809990458.

MacEachern, J.A. \& Gingras, M.K. 2007. Recognition of brackish-water trace-fossil suites in the Cretaceous Western Interior Seaway of Alberta, Canada. In: Sediment-Organism Interactions: a Multifaceted Ichnology (eds. Bromley, R., Buatois, L.A., Genise, J., Mángano, M.G. \& Melchor, R.). SEPM, Special Publication, 88, 249-194.

MacEachern, J.A., Raychaudhuri, I. \& Pemberton. S.G. 1992. Stratigraphic applications of the Glossifungites ichnofacies: Delineating discontinuities in the rock record. In: Applications of Ichnology to Petroleum Exploration, a Core Workshop (ed. Pemberton, S.G.). SEPM, Core Workshop, 17, 169-198.

Mata, S.A. \& Bottjer, D.J. 2011. Origin of Lower Triassic microbialites in mixed carbonate-siliciclastic successions: ichnology, applied stratigraphy, and the end-Permian mass extinction. Palaeogeography, Palaeoclimatology, Palaeoecology, 300, 158-178; doi: $10.1016 / \mathrm{j}$. palaeo.2010.12.022.

Mattioli, E., Pittet, B., Petitpierre, L. \& Mailliot S. 2009. Dramatic decrease of pelagic carbonate production by nannoplankton across the Early Toarcian anoxic event
(T-OAE). Global and Planetary Change, 65, 134-145; doi: 10.1016/ j.gloplacha.2008.10.018.

McArthur, J.M., Algeo, T.J., van de Schootbrugge, B., Li, Q. \& Howarth R.J. 2008. Basinal restriction, black shales, Re-Os dating, and the Early Toarcian (Jurassic) oceanic anoxic event. Paleoceanography, 23; doi: 10.1029/2008PA001607.

McElwain, J.C., Wade-Murphy, J. \& Hesselbo, S.P. 2005. Changes in carbon dioxide during an oceanic anoxic event linked to intrusion into Gondwana coals. Nature, 435, 479-482; doi: 10.1038/nature03618.

Melchor, R.N., Bromley, R. \& Bedatou, E. 2009. Spongeliomorpha in nonmarine settings: an ichnotaxonomic approach. Earth and Environmental Science Transactions of the Royal Society of Edinburgh, 100, 429-436; doi: 10.1017/S1755691009008056.

Miguez-Salas, O., Rodríguez-Tovar, F.J. \& Duarte, L.V. 2017. Selective incidence of the Toarcian Oceanic Anoxic Event (T-OAE) on macroinvertebrate marine communities: a case from the Lusitanian basin (Portugal). Lethaia, 50, 548-560; doi: 10.1111/let.12212.

Mikulàš, R. 1990. Ichnologic note: The ophiuroid Taeniaster as a tracemaker of Asteriacites, Ordovician of Czechoslovakia. Ichnos, 1, 133-137; doi: 10.1080/10420949009386342.

Monaco, P. \& Garassino, A. 2001. Burrows and body fossil of decapod crustaceans in the Calcari Grigi, lower Jurassic, Trento platform (Italy). Geobios, 34, 291-301; doi: 10.1016/S0016-6995(01)80077-2.

Monaco, P. \& Giannetti, A. 2002. Three-dimensional burrow systems and taphofacies in shallowing-upward parasequences, Lower Jurassic Carbonate Platform (Calcari Grigi, southern Alps, Italy). Facies, 47, 57-82; doi: 10.1007/BF02667706.

Monaco, P., Rodríguez-Tovar, F.J. \& Uchman, A. 2015. A delayed response of the trace fossil community at the Cretaceous-Paleogene boundary in the Bottaccione section, Gubbio, Central Italy. Geobios, 48, 137-145; doi: 10.1016/j.geobios.2015.02.001.

Muñiz, F. \& Mayoral, E. 2001. El icnogénero Spongeliomorpha en el Neógeno superior de la cuenca de Guadalquivir (área Lepe-Ayamonte, Huelva, España). Revista Española de Paleontología, 16, 115-30.

Myrow, P.M. 1995. Thalassinoides and the enigma of Early Paleozoic open-framework burrow systems. Palaios, 10, 58-74; doi: $10.2307 / 3515007$.

Nickell, L.A. \& Atkinson, R.J.A. 1995. Functional morphology of burrows and trophic modes of three thalassinidean shrimp species, and a new approach to the classification of thalassinidean burrow morphology. Marine Ecology Progress Series, 128, 181-197; doi: 10.3354/meps128181.

Nieto, L.M., Rodríguez-Tovar, F.J., Molina, J.M., Reolid, M. \& Ruiz-Ortiz, P.A. 2014. Unconformity surfaces in pelagic carbonate environments: A case from the Middle Bathonian of the Betic Cordillera, SE Spain. Annales Societatis Geologorum Poloniae, 84, 281-295.

Olóriz, F. \& Rodríguez-Tovar, F.J. 2000. Diplocraterion: A useful marker for sequence stratigraphy and correlation in the Kimmeridgian, Jurassic (Prebetic Zone, Betic 
Cordillera, southern Spain). Palaios, 15, 546-552; doi: 10.1669/0883-1351.

Pálfy, J. \& Smith, P. L. 2000. Synchrony between Early Jurassic extinction, oceanic anoxic event, and the KarrooFerrar flood basalt volcanism. Geology, 28, 747-750; doi: 10.1130/0091-7613.

Pemberton, S.G. \& MacEachern. J.A. 1995. The sequence stratigraphic significance of trace fossils: Examples from the Cretaceous foreland basin of Alberta, Canada. In: Sequence Stratigraphy of Foreland Basin Deposits - Outcrop and Subsurface Examples from the Cretaceous of North America (eds. Van Wagoner, J.C. \& Bertram, G.). American Association of Petroleum Geologists, 64, 429-475.

Pemberton, S.G., MacEarchern, J.A. \& Saunders, T. 2004. Stratigraphic applications of substrate-specific ichnofacies: delineating discontinuities in the rock record. In: The Application of Ichnology to Palaeoenvironmental and Stratigraphic Analysis (ed. McIlroy, D.). Special Publication Geological Society, London, 228, 29-62; doi: 10.1144/GSL. SP.2004.228.01.03.

Pittet, B., Suan, G., Lenoir, F., Duarte, L.V. \& Mattioli, E. 2014. Carbon isotope evidence for sedimentary discontinuities in the lower Toarcian of the Lusitanian Basin (Portugal): sea level change at the onset of the oceanic anoxic event. Sedimentary Geology, 303, 1-14; doi: 10.1144/GSL. SP.2004.228.01.03.

Reolid, M., Mattioli, E., Nieto, L.M. \& Rodríguez-Tovar, F.J. 2014. The Early Toarcian Oceanic Anoxic Event in the external subbetic (South Iberian Palaeomargin,Westernmost Tethys): geochemistry, nannofossils and ichnology. Palaeogeography, Palaeoclimatology, Palaeoecology, 411, 79-94; doi: 10.1016/j.palaeo.2014.06.023.

Reolid, M., Rivas, P. \& Rodríguez-Tovar, F.J. 2015. Toarcian ammonitico rosso facies from the South Iberian Paleomargin (Betic Cordillera, southern Spain): paleoenvironmental reconstruction. Facies, 61, 22; doi: 10.1007/s10347-0150447-3.

Rieth, A. 1932. Neue Funde spongeliomorpher Fucoiden aus Jura Schwabens. Miteiner zusammenfassenden Übersicht ahnlicher Gebilde aus triassischen und kretazischen Schichten Deutschlands. Geologische und Palaöntogische Abhandlungen, 19, 257-294.

Rita, P., Reolid, M. \& Duarte, L.V. 2016. Benthic foraminiferal assemblages record major environmental perturbations during the Late Pliensbachian-Early Toarcian interval in the Peniche GSSP, Portugal. Palaeogeography, Palaeoclimatology, Palaeoecology, 454, 267-281; doi: 10.1016/j.palaeo.2016.04.039.

Rodrigues, B., Duarte, L.V., Mendonça Filho, J.G., Santos, L.G. \& Oliveira, A.D. 2016. Evidence of terrestrial organic matter deposition across the early Toarcian recorded in the northern Lusitanian Basin, Portugal. International Journal of Coal Geology, 168, 35-45; doi: 10.1016/j.coal.2016.06.016.

Rodríguez-Tovar, F.J. 2005. Fe-oxide spherules infilling Thalassinoides burrows at the Cretaceous-Paleogene (K-P) boundary: Evidence of a near-contemporaneous macrobenthic colonization during the K-P event. Geology, 33, 585-588; doi: 10.1130/G21527.1.
Rodríguez-Tovar, F.J. 2010. Ichnological analysis and sequence stratigraphy research: present-day and prospective. Memoir Geological Society of India, 75, 99-114.

Rodríguez-Tovar, F.J. \& Nieto, L.M. 2013. Composite trace fossil assemblage in distal carbonate swell settings from the pelagic Tethyan Domain (Middle Jurassic, Betic Cordillera, southern Spain). Ichnos, 20, 43-53; doi: 10.1080/10420940.2013.778844.

Rodríguez-Tovar, F.J. \& Pérez-Valera, F. 2008. Trace fossil Rhizocorallium from the Middle Triassic of the Betic Cordillera, southern Spain: characterization and environmental implications. Palaios, 23, 78-86; doi: 10.2110/palo.2007.p07-007r.

Rodríguez-Tovar, F.J. \& Reolid, M. 2013. Environmental conditions during the Toarcian Oceanic Anoxic Event (T-OAE) in the westernmost Tethys: influence of the regional context on a global phenomenon. Bulletin of Geoscience, 88, 697-712; doi: 10.3140/bull.geosci.1397.

Rodríguez-Tovar, F.J. \& Uchman, A. 2004a. Trace fossils after the K-T boundary event from the Agost section, SE Spain. Geological Magazine, 141, 429-440; doi: 10.1017/ S0016756804009410.

Rodríguez-Tovar, F.J. \& Uchman, A. 2004b. Ichnotaxonomic analysis of the Cretaceous/Palaeogene boundary interval in the Agost section, southeast Spain. Cretaceous Research, 25, 635-647; doi: 10.1016/j.cretres.2004.06.003.

Rodríguez-Tovar, F.J. \& Uchman, A. 2006. Ichnological analysis of the Cretaceous-Palaeogene boundary interval at the Caravaca section, SE Spain. Palaeogeography, Palaeoclimatology, Palaeoecology, 242, 313-325; doi: 10.1016/j.palaeo.2006.06.006.

Rodríguez-Tovar, F.J. \& Uchman, A. 2008. Bioturbational disturbance of the Cretaceous-Palaeogene (K-Pg) boundary layer: implications for the interpretation of the K-Pg boundary impact event. Geobios, 41, 661-667; doi: 10.1016/j.geobios.2008.01.003.

Rodríguez-Tovar, F.J. \& Uchman, A. 2010. Ichnofabric evidence for the lack of bottom anoxia during the Lower Toarcian Oceanic Anoxic Event in the Fuente de la Vidriera section, Betic Cordillera, Spain. Palaios, 25, 576-587; doi: 10.2110/palo.2009.p09-153r.

Rodríguez-Tovar, F.J., Martínez-Ruíz, F. \& Bernasconi, S.M. 2004. Carbon isotope evidence of the CretaceousPalaeogene macrobenthic colonization at the Agost section (southeast Spain). Palaeogeography, Palaeoclimatology, Palaeoecology, 203, 65-72; doi: 10.1016/S00310182(03)00660-6.

Rodríguez-Tovar, F.J., Martínez-Ruíz, F. \& Bernasconi, S.M. 2006. Use of high-resolution ichnological and stable isotope data for assessing completeness of a K-Pg boundary section, Agost, Spain. Palaeogeography, Palaeoclimatology, Palaeoecology, 237, 137-146; doi: 10.1016/j.palaeo.2005.11.019.

Rodríguez-Tovar, F.J., Pérez-Valera. F. \& Pérez-López, A. 2007. Ichnological analysis in high-resolution sequence stratigraphy: the Glossifungites Ichnofacies in Triassic successions from the Betic Cordillera (southern Spain). 
Sedimentary Geology, 198, 293-307; doi: 10.1016/j. sedgeo.2007.01.016.

Rodríguez-Tovar, F.J., Puga-Bernabéu, Á. \& Buatois, L.A. 2008. Large burrow systems in marine Miocene deposits of the Betic Cordillera (Southeast Spain). Palaeogeography, Palaeoclimatology, Palaeoecology, 268, 19-25; doi: 10.1016/j.palaeo.2008.07.022.

Rodríguez-Tovar, F.J., Uchman, A., Molina, E. \& Monechi, S. 2010. Bioturbational redistribution of Danian calcareous nannofossils in the uppermost Maastrichtian across the K-Pg boundary at Bidart, SW France. Geobios, 43, 569579; doi: 10.1016/j.geobios.2010.03.002.

Rodríguez-Tovar, F.J., Uchman, A., Orue-Etxebarria, X., Apellaniz, E. \& Baceta, J.I. 2011. Ichnological analysis of the Bidart and Sopelana Cretaceous/Paleogene (K/Pg) boundary sections (Basque Basin, WPyrenees): refining eco-sedimentary environment. Sedimentary Geology, 234, 42-55; doi: 10.1016/j.sedgeo.2010.11.004.

Rodríguez-Tovar, F.J., Uchman, A., M'Hamdi, A., Riahi, S. \& Ismail-Lattrache, K.B. 2016. Ichnological record of palaeoenvironment from the Cretaceous-Paleogene boundary interval at El Kef, Tunisia: the first study of old and new sections at the stratotype area. Journal of African Earth Science, 120, 23-30; doi: 10.1016/j. jafrearsci.2016.04.017.

Rodríguez-Tovar, F.J., Miguez-Salas, O. \& Duarte, L.V. 2017. Toarcian Oceanic Anoxic Event induced unusual behaviour and palaeobiological changes in Thalassinoides tracemakers. Palaeogeography, Palaeoclimatology, Palaeoecology, 485, 46-56; doi: 10.1016/j.palaeo.2017.06.002.

Röhl, A., Röhl, H.-J., Oschmann, W., Frimmel, A. \& Schwark, L. 2002. Palaeoenvironmental reconstruction of Lower Toarcian epicontinental black shales (Posidonia Shale, SW Germany): global versus regional control. Geobios, 35, 13-20; doi: 10.1016/S0016-6995(02)00005-0.

Saporta, G. de. 1887. Nouveaux documents relatifs aux organismes problématiques des anciennes mers. Societé Géologique de France, Bulletin Series 3, 15, 286-302.

Suan, G., Pittet, B., Bour, I., Mattioli, E., Duarte, L.V. \& Mailliot, S. 2008. Duration of the Early Toarcian carbon isotope excursion deduced from spectral analysis: consequence for its possible causes. Earth and Planetary Science Letters, 267, 666-679; doi: 10.1016/j. eps1.2007.12.017.

Suan, G., Mattioli, E., Pittet, B., Lécuyer, C., Suchéras-Marx, B., Duarte, L.V., Philippe, M., Reggiani, L. \& Martineau, F. 2010. Secular environmental precursors to Early Toarcian (Jurassic) extreme climate changes. Earth and Planetary Science Letters, 290, 448-458; doi: 10.1016/j. eps1.2009.12.047.

Suan, G., Nikitenko, B.L., Rogov, M.A., Baudin, F., Spangenberg, J.E., Knyazev, V.G., Glinskikh, L.A., Goryacheva, A.A., Adatte, T., Riding, J.B., Föllmi, K.B., Pittet, B., Mattioli, E. \& Lécuyer, C. 2011. Polar record of Early Jurassic massive carbon injection. Earth and Planetary Science Letters, 312, 102-113; doi: 10.1016/ j.eps1.2011.09.050.
Svensen, H., Planke, S., Chevallier, L., Malthe-Sørenssen, A., Corfu, F. \& Jamtveit, B. 2007. Hydrothermal venting of greenhouse gases triggering Early Jurassic global warming. Earth and Planetary Science Letters, 256, 554-566; doi: 10.1016/j.eps1.2007.02.013.

Trecalli, A., Spangenberg, J., Adatte, T., Föllmi, K.B. \& Parente, M. 2012. Carbonate platform evidence of ocean acidification at the onset of the early Toarcian oceanic anoxic event. Earth and Planetary Science Letters, 357358, 214-225; doi: 10.1016/j.eps1.2012.09.043.

Twitchett, R.J. \& Barras, C.G. 2004. Trace fossils in the aftermath of mass extinction events. In: The Application of Ichnology to Palaeoenvironmental and Stratigraphic Analysis (ed. McIlroy, D.). Geological Society Special Publication, 228, 397-418; doi: 10.1144/ GSL.SP.2004.228.01.18.

Uchman, A. 1998. Taxonomy and ethology of flysch trace fossils: revision of the Marian Ksiàkiewicz collection and studies of complementary material. Annales Societatis Geologorum Poloniae, 68, 2-3, 105-218.

van Breugel, Y., Baas, M., Schouten, S., Mattioli, E. \& Sinninghe Damsté, J.S. 2006. Isorenieratane record in black shales from the Paris Basin, France: Constraints on recycling of respired $\mathrm{CO}_{2}$ as a mechanism for negative carbon isotope shifts during the Toarcian oceanic anoxic event. Paleoceanography, 21, doi: 10.1029/2006PA001305.

Vörös, A. 2002. Victims of the early Toarcian anoxic event: the radiation and extinction of Jurassic Koninckinidae (Brachiopoda). Lethaia, 35, 345-357; doi: 10.1111/j.15023931.2002.tb00093.x.

Wang, Y. 2004. Some trace fossils after the FrasnianFamennian extinction in the Dushan area, southern Guizhou Province, China. Acta Palaeontologica Sinica, 43, 132-141.

Whicher, J., Collins, J.S.H., Chandler, R.B., Dodge, M. \& Davey, S. 2016. The fossil macrurous Crustacean Glyphea from within Thalassinoides burrows in the Inferior Oolite Formation of Frogden Quarry, Oborne, Dorset, UK. Proceedings of the Geologists' Association, 127, 189-195; doi: 10.1016/j.pgeola.2015.12.007.

Wignall, P.B. \& Bond, D.P.G. 2008. The end-Triassic and Early Jurassic mass extinction records in the British Isles. Proceedings of the Geologists' Association, 119, 73-84; doi: 10.1016/S0016-7878(08)80259-3.

Wignall, P.B., Newton, R.J. \& Little, C.T.S. 2005. The timing of paleoenvironmental change and cause-and-effect relationships during the Early Jurassic mass extinction in Europe. American Journal of Science, 305, 1014-1032; doi:10.2475/ajs.305.10.1014.

Woodward, S. 1830. A synoptic table of British organic remains. Geology of Norfolk, 8.

Wright, V.P \& Wilson, R.C.L. 1984. A carbonate submarinefan sequence from the Jurassic of Portugal. Journal of Sedimentary Petrology, 54, 394-412.

Yanin, B.T. \& Baraboshkin, E.Y. 2013. Thalassinoides burrows (Decapoda dwelling structures) in lower Cretaceous sections of Southwestern and Central Crimea. Stratigrafiya Geologicheskaya, Korrelyatsiya, 21, 39-49. 